\title{
The Effect of the Implementation of Mind Mapping Method on Critical Thinking Skills in Civic Education Learning
}

\author{
Resti Anika Sari ${ }^{1 *}$, Mukhamad Murdiono² \\ 1,2 Yogyakarta State University, Yogyakarta, Indonesia \\ *e-mail: restianikasari95@gmail.com
}

\begin{abstract}
One of the efforts made to produce quality human resources in a developing country like Indonesia is to carry out development in all fields. In the field of education, various efforts to improve the quality of education are always carried out. This study aims to analyze the effect of the implementation of Mind Mapping method on the critical thinking skills of grade $X$ students in civic education learning. This research is a quasi-experimental study using quantitative approach. The research sample was 62 students divided into 2 classes who were selected using random sampling technique. Data were collected by conducting pre-test and post-test. Hypothesis testing using t-test analysis with a significance level of the analysis results was determined at $5 \%$. The result showed that there was an effect of the implementation of Mind Mapping method in learning civic education on the critical thinking skills of class $X$ students. This is indicated by the increase of $t_{\text {count }}$ of the post-test that is 7.923. In addition, the table on df 60 was 2.000, and the significance value of 0.000 was smaller than the significance level of $5 \%(0.000<0.05)$. Mind mapping as a learning method can be used as a solution to improve students' critical thinking in the learning process in order to achieve learning goals.
\end{abstract}

Keywords: Mind Mapping Method, Critical Thinking, Civic Education

\section{Introduction}

One of the efforts made to produce quality human resources in a developing country like Indonesia is to carry out development in all fields. In the field of education, various efforts to improve the quality of education are always carried out in various ways to form competent human resources who are able to compete in the global era (Habiby et al., 2017; Rohmawati et al., 2018). As a process, education is not just a transfer of knowledge, but rather a transfer of values. Through the education sector, it is hoped that it will be able to produce quality humans in order to educate the people of the nation. The ultimate goal of education is to create complete human beings who have the knowledge and values of piety to the God Almighty in order to educate the people of the nation (Sudarmiani, 2013; Sujana, 2019). The success and achievement of educational goals in schools are essentially the responsibility of all parties from the school, the government, and the community. The learning process at school is not only the responsibility of the school, but the family also plays a role in monitoring the continuation of learning from school to home (Lilawati, 2020; Swalwell \& Payne, 2019). However, in practice, school plays a greater role in realizing educational goals through the role of teachers in schools. One of the subjects studied in all levels of education is civic education. Since this education is important, it has been implemented at every level of education from the earliest to the highest education in order to produce competent generation for the nation and state. Civic education is a subject whose main focus emphasizes the formation of oneself from various cultures and ethnic groups in order to become smart, skilled, and characterized citizens mandated by Pancasila and the 1945 Constitution.

Conceptually, civic education is a multi-faceted field of study from a cross-disciplinary context called interdisciplinary and multidimensional based on social science discipline theory which is structurally based on political science disciplines (Dewantara et al., 2019; Khoeriyah \& Mawardi, 2018). Civic education discusses the preparation for humans to become citizens who are equipped with three elements of knowledge, namely civic knowledge, civic skills, and

\footnotetext{
${ }^{*}$ Corresponding author.

Received December 21, 2020; Accepted April 10, 2021; Available online September 25, 2021

Copyright @ 2021 by Author. Published by Universitas Pendidikan Ganesha.
}

Jurnal Pendidikan Indonesia (JPI) | 505 
civic disposition (Davies et al., 2017). These three components form the basis for the citizens to participate in society (Schulz et al., 2016). The point is that citizens, in addition to having civic knowledge, must also have civic skills including intellectual and participatory skills which will be developed in the formation of democratic civic disposition. Schools have an important role in developing civic competence (Print \& Lange, 2013).

Civic education is a very important component of democratic education because it encourages citizens to participate more in public life (Cholisin, 2005). This participation includes exercising rights and responsibilities with the knowledge and skills needed to form a good citizen (how a good citizen). The presence of civic education, especially for adolescents, can improve problem solving abilities, interpersonal skills and communication skills, increase self-confidence, ethical awareness, social responsibility, and empathy; and facilitate open-mindedness, acceptance of differences, and tolerance for others and society (Lee, 2015). It is not easy for students to achieve citizenship element without a quality learning process. Learning process is one of the factors that can determine students' learning outcomes (In'am \& Hajar, 2017). In contrast to 2006 curriculum which only emphasizes knowledge competencies and is teacher-centered (Habiby et al., 2017), the 2013 curriculum emphasizes the balance between soft skills and hard skills where students are expected to master the competence of attitude, skills, and knowledge as a provision for 21 st century skills. The 21 st century skills which include (a) critical thinking and problem solving, (b) communication, (c) collaboration, and (d) creativity and innovation are skills that students must possess in accordance with the development of science and technology (Hamdu et al., 2020; Vasil, 2020).

A person must have these abilities in order to compete with the outside world (Afandi et al., 2019; Boholano, 2017; Jan, 2017). In addition, the 2013 curriculum also requires teachers to design and implement creative, innovative, and strategic learning models and strategies that place students as the focus of learning so that students become independent and responsible in the learning process (Handayani, 2017; Santosa, 2017). These strategies should help students to develop critical thinking and problem solving skills (Changwong et al., 2018; Machdel \& Marita, 2019). The role of teacher in classroom learning is that teacher must be able to understand the material, understand how to teach in class effectively, and serve students as a learning facilitator (Shume et al., 2012). One of the important 21st century skills is critical thinking. It is widely recognized as an important academic skill and is a general skill emerging at the very top that contributes to academic success and careers in the 21st century where individuals have the ability to think analytically, interpret, accurately, solve problems, and express opinions in building the knowledge they have learned (Aliftika et al., 2019; Cole et al., 2015; Kettler, 2014; Shaw et al., 2019). Critical thinking is meant to think for positive purposes because it is impossible that in the various aspects of life including the education sector to wish for it to be used with negative interests. It may be worth noting that the term critical thinking is often used in educational context because school must be the center of freedom and dialogue (Elicor, 2016).

The ability to think critically is important because a person's ability to succeed in life is determined in part by his thinking ability. In addition, the ability to think acts as a means to achieve educational goals so that students are able to solve high level problems (Dwijananti \& Yulianti, 2010). Critical thinking is defined as the ability to analyze and evaluate evidence, identify questions, and build logical conclusions (Mahanal et al., 2019). Critical thinking is also defined as the ability to think reflectively and skillfully as a tool to facilitate decision making or problem solving so that a person can decide what information can be relied on and what actions to take during reasoning and problem solving (Kong, 2015; Roohr \& Burkander, 2020). Someone who has the ability to think critically will be at a complex level of thought that they can analyze and evaluate each study to take an action. Someone who has the ability to think critically are able to think in a better, clearer, more accurate and more defensible way (Mehta \& Al-Mahroogi, 2014).

In order to get student, think critically in civic education learning process, a variety of learning methods are needed. One of them is the mind mapping method. The learning process using mind mapping method promotes students to take high-level notes by utilizing 
the entire brain and allows them to explore all brain capabilities namely the right brain and the left brain for thinking and learning purposes. Mind mapping is a learning strategy used for problem solving, organizing ideas, improving memory, storytelling, and exchanging ideas (Kernan et al., 2017). The learning process using the mind mapping method which utilizes the whole brain in thinking is very effective in developing students' critical thinking skills. When the teacher applies mind mapping as a learning method, each student will think by interpreting, analyzing, summarizing, and evaluating/concluding the assignment and material that has been given by the teacher to further solve the material/task problem. A previous research supported this notion that the learning model Synestics, Mind Maps, Cooperative Learning (SM2CL) has a positive effect on critical thinking skills (Taufik et al., 2018).

The result of observation regarding civic education learning at SMK Negeri 1 Yogyakarta revealed that the methods used in the learning process were still considered as less varied. Civic education at SMK Negeri 1 Yogyakarta was taught with the usual lecture and discussion methods. Thus, the students' main activity in the learning process only consisted of taking notes. Consequently, they became less active in learning activities and could not understand the learning material very well. In addition, some students have not been able to think meaningfully in identifying the assumptions given by the teacher and formulating the main problems of the material presented by the teacher because most of them only stuck to handbook. Therefore, they were unable to think very well in expressing their ideas. In connection with the problems that have been described, it is thus necessary to find a solution, especially regarding good learning methods to improve the critical thinking skills of students in learning civic education. The purpose of applying methods that promote students to think critically and not only focused on the teacher is to produce meaningful educational outcomes. If students can think critically, it means that they have the skills needed in the 21 st century to succeed and meet the needs of the global economy (Hewett et al., 2018). This study aims to analyze the effect of the mind mapping method on students' critical thinking skills in civic education learning. The effect of the mind mapping method on critical thinking skills was measured from the results of pre-test and post-test of the experimental class group and the control class group before and after treatment. This study contributes to our understanding of mind mapping as a learning method for critical thinking skills. Further, the findings can be used as an input to increase the role of schools and teachers in the effort to improve the quality of students.

\section{Method}

This research is quasi-experimental research using the Nonequivalent Control Group research design. The population of this study was 188 students of class X SMK Negeri 1 Yogyakarta who were divided into 6 classes. Meanwhile, the sample in this study was 1 experimental class group and 1 control class group with a total of 62 students. This study used random sampling techniques (randomly selected based on class). The reason using simple random sampling was because the population was homogeneous/has the same possibility of being selected along with the consideration that the researcher used two classes as the experimental class group and the control class group (Creswell, 2016). The research design is presented in Table 1.

Table 1. Research Design of Nonequivalent Control Group Design

\begin{tabular}{lccc}
\hline Group & Pre-test & Treatment & Post-test \\
\hline Eksperimental & $\mathrm{O}_{1}$ & $X$ & $\mathrm{O}_{2}$ \\
Control & $\mathrm{O}_{3}$ & - & $\mathrm{O}_{4}$ \\
\hline
\end{tabular}

The study began with giving pre-test questions to the two class groups to determine the basic abilities of students. Then, they were given different treatment where the experiment class group learned using mind mapping method and the control class group 
learned without using mind mapping method, namely lecture and discussion. The last stage was the provision of post-test questions to the two class groups to determine the final abilities of students especially students' critical thinking skills. The instrument used in this study were test questions in the form of essay which were divided into pre-test and post-test questions; each of which consisted of 5 essay questions. The test questions were adjusted to the subject matter namely Archipelago Insights in the context of the Unitary State of the Republic of Indonesia. The research instrument has passed the process of testing to determine its validity and reliability. Instrument testing was conducted in 2 classes using statistical tests with the formula Product Moment Coefficient from Karl Pearson and Alpha Cronbach. Validity was also conducted by using the opinion of experts. This was done by consulting the instrument to experts assisted by using instrument grid.

The data analysis technique used in this study was descriptive statistics. There were two tests performed namely the analysis prerequisite test and hypothesis testing. The prerequisite analysis consisted of two types: the normality test and the homogeneity test. The normality test used in this study was Kolmogrov-Smirnov test in the SPSS program. The criterion for acceptance of normality is as follows: when the significance value of the calculation results is greater than $\alpha=0.05$, the distribution is said to be normal. Conversely, if it is smaller than $\alpha=0.05$, then the distribution is said to be abnormal. Further, the homogeneity test applied to the data obtained from the final pre-test and post-test scores of the experimental class group and the control class group was calculated using Levene test. The variance requirement is said to be homogeneous if the significance is greater than 0.05 or $F_{\text {count }}<F_{\text {table. }}$ SPSS 20.0 for Windows was used to test the hypothesis by conducting t-test with Paired Sample T-test analysis. Analysis of the Paired Sample T-test was used to see whether the variables had influence/relationship or not. Then, the results of the test were used to prove whether there was an effect of the implementation of mind mapping method in learning civic education on the critical thinking skills of class $X$ students of SMK Negeri 1 Yogyakarta. The criteria for acceptance of the hypothesis is at a significance level of $5 \%$ or the data requirements are significant if $p$ is less than 0.05 or $t_{\text {count }}>t_{\text {table. }}$. Meanwhile, if $t_{\text {count }}<$ $t_{\text {table }}$ then Ho is rejected.

\section{Result and Discussion}

\section{Results}

The basis for decision making in the validity test is that if the value of $r$ count $\geq r$ table, then it is declared valid. Conversely, if the value of $r$ count $<r$ table, then it is declared invalid. In this study, it was concluded that all questions were declared valid because $r$ count $\geq r$ table. Furthermore, the instrument used in the study was reliable with a Cronbach Alpha value $>0.06$. Therefore, it could be trusted. The results of the validity and reliability of the pre-test and post-test instruments, each of which consisted of 5 essay questions, are presented in Table 2 and Table 3.

Table 2. Validity Test Results

\begin{tabular}{ccccc}
\hline Instrument & Item & r Count & r Table & Information \\
\hline \multirow{3}{*}{ Pre-test } & 1 & 0.591 & 0.355 & Valid \\
& 2 & 0.411 & 0.355 & Valid \\
& 3 & 0.942 & 0.355 & Valid \\
& 4 & 0.921 & 0.355 & Valid \\
Post-test & 5 & 0.574 & 0.355 & Valid \\
& 1 & 0.942 & 0.355 & Valid \\
& 2 & 0.614 & 0.355 & Valid \\
& 3 & 0.622 & 0.355 & Valid \\
& 4 & 0.895 & 0.355 & Valid \\
& 5 & 0.566 & 0.355 & Valid \\
\hline
\end{tabular}


Table 3. Reliability Test Results

\begin{tabular}{lccl}
\hline Instrument & Cronbach Alpha & Critical Value & Information \\
\hline Pre-Test & 0.759 & 0.6 & Reliable \\
Post-Test & 0.781 & 0.6 & Reliable \\
\hline
\end{tabular}

The data from the pre-test results of the control class group and the experimental class group before treatment are presented in Figure 1 and Figure 2.

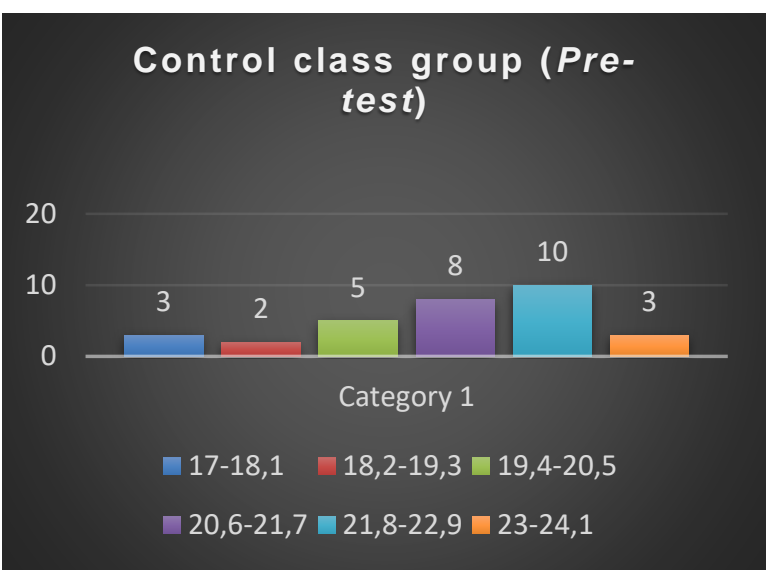

Figure 1. Frequency distribution of the pretest of control class group

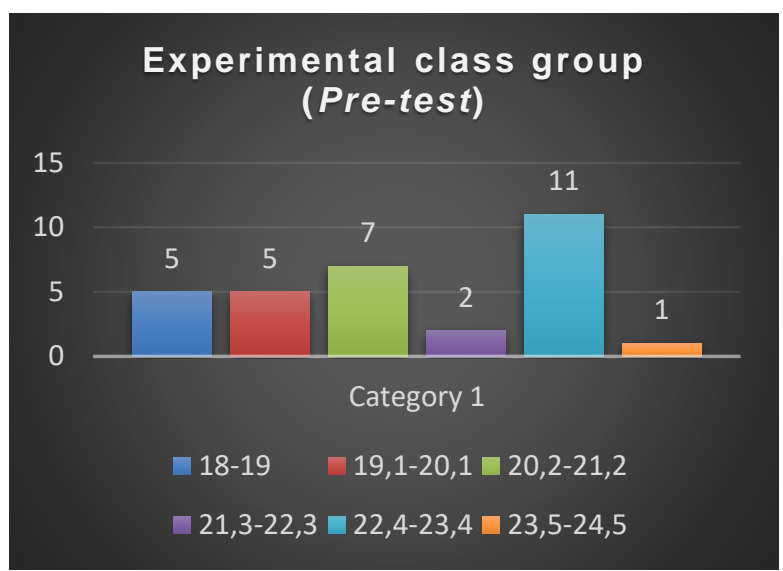

Figure 2. Frequency distribution of the pretest of experimental class group

The data of the post-test result from the control class group and the experimental class group after the treatment are presented in Figure 3 and Figure 4.

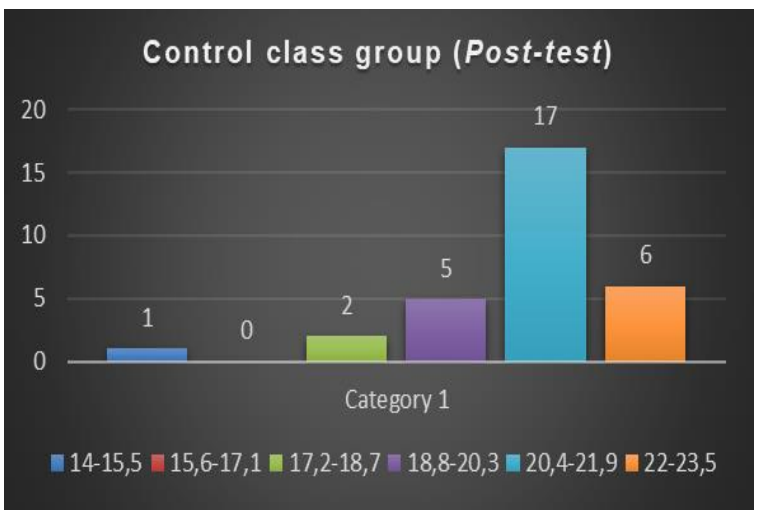

Figure 3. Frequency distribution of the posttest of control class group

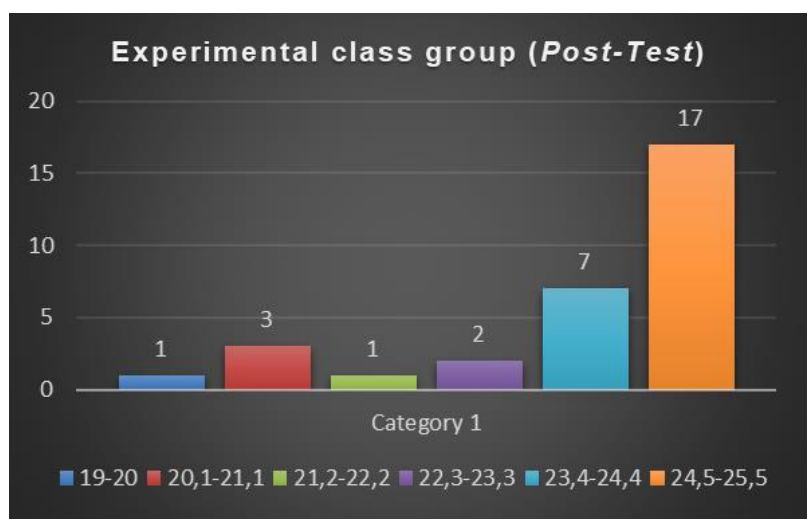

Figure 4. Frequency distribution of the posttest of experimental class group

Based on the data from the pre-test and post-test results of both the experimental class group and the control class group, it was found that the lowest score was 14 and the highest score was 25. The distribution of the pre-test and post-test scores in both the experimental class group and the control class group is presented in Table 4. The normality test was carried out on the pre-test and post-test of both the experimental class group and the control class group. Based on the results of calculations using SPSS version 20.0 program, it was found that the distribution of data in this study was normally distributed because it had a significance value greater than 0.05 at $(p>0.05)$. Thus, these data have fulfilled the requirements for analysis. The results of the normality test are presented in Table 5. 
Table 4. Distribution of Pre-test and Post-test Results

\begin{tabular}{llllll}
\hline \multirow{2}{*}{ No } & \multirow{2}{*}{ Score } & \multicolumn{2}{c}{ Experimental Class } & \multicolumn{2}{c}{ Control Class } \\
\cline { 2 - 6 } & & Pre-test & Post-test & Pre-test & Post-test \\
\hline 1 & $18.3-25$ & 28 & 31 & 28 & 28 \\
2 & $11.7-18.2$ & 3 & 0 & 3 & 3 \\
3 & $5-11.6$ & 0 & 0 & 0 & 0 \\
\hline
\end{tabular}

Table 5. Normality Test Results

\begin{tabular}{clcc}
\hline No & \multicolumn{1}{c}{ Data } & Sig (p) & Information \\
\hline 1 & Pre-test of Experimental Class Group & 0.194 & Normal \\
2 & Post-Test of Experimental Class & 0.141 & Normal \\
3 & Group & 0.195 & Normal \\
4 & Post-test of Control Class Group & 0.250 & Normal \\
\hline
\end{tabular}

The homogenity test was conducted to determine the similarity of variance in the pretest and post-test for experimental class group and control class group. The results of the calculation showed that the data had homogeneous variance because the significance value was greater than $5 \%(p>0.05)$ or has $F_{\text {count }}<F_{\text {table }}$. Thus, the data has met the requirements for analysis and further hypothesis testing was conducted. The results of the homogenity test are shown in Table 6.

Table 6. Homogeneity Test Results

\begin{tabular}{cccccc}
\hline No & Data & Fcount & Ftable & Sig & Information \\
\hline 1 & Pre-test & 0.008 & 3.15 & 0.931 & Homogen \\
2 & Post-test & 0.240 & 3.15 & 0.626 & Homogen \\
\hline
\end{tabular}

The hypothesis of this study is "There is an effect of the implementation of mind mapping method in civic education learning on the critical thinking skills of class $X$ students of SMK Negeri 1 Yogyakarta". The results of the t-test between the experimental class group and the control class group are presented in Table 7.

Table 7. The results of the t-test between the experimental class group and the control class group

\begin{tabular}{ccccc}
\hline Data & t-count & df & P & Information \\
\hline $\begin{array}{c}\text { Experimental class } \\
\text { group and control } \\
\text { class group }\end{array}$ & 7.923 & 60 & 0.000 & $\begin{array}{c}\text { Significance } \\
(P=0.000<0.05)\end{array}$ \\
\hline
\end{tabular}

From Table 7, it can be seen that the $t_{\text {count }}$ is 7.923 and $t_{\text {tabel }}$ value with df 60 at the $5 \%$ significance level is 2.000 . The value of $t_{\text {count }}>t_{\text {table, }}$, or the $p$ value is less than $0.05(p=0.000$ $<0.05)$. Thus, the result of the t-test indicates that the hypothesis was accepted. In other words, there was an effect of the application of the mind mapping method in civic education learning on the critical thinking abilities of class X students of SMK Negeri 1 Yogyakarta.

\section{Discussion}

Based on the research results that have been described, there is an effect of the application of mind mapping method in civics education learning on the critical thinking skills of class $X$ students of SMK Negeri 1 Yogyakarta. This is indicated by the value of $t_{\text {count }}$ on the critical thinking post-test that was greater than 7.923. In addition, the $t_{\text {table }}$ on df 60 was 2.000, and a significance value of 0.000 was smaller than the significance level of $5 \%(0.000<$ 0.05). The results of this study supported previous research where the results of their 
research showed that the learning model Synestics, Mind Maps, Cooperative Learning (SM2CL) had a positive effect on critical thinking skills (Taufik et al., 2018). There was a difference in the results of the critical thinking ability test before and after being given treatment with the SM2CL learning model because the post-test mean score of the experimental class (87.92) was higher than the post-test average score of the control class (69.61).

The purpose of education in schools is more emphasized on the mastery of knowledge and skills that can provide provisions for students in facing daily life (Rachmadtullah \& Wardani, 2016). The application of various methods in order to achieve the learning objectives needs to be applied in civic education learning including applying the mind mapping method. The main purpose of civic education in the 2013 curriculum is none other than fostering competence in the exchange of ideas and effective communicative skills and encouraging students to be cooperative, critical, and active so as to provide experience and practice in the concept of national and state life both inside and outside classroom (Hung, 2014; Samsuri, 2013). Civic education learning must be actualized in a fun way in accordance with daily activities and the current development. This is supported by selecting appropriate teaching materials, instructional media and learning methods, and applying the mind mapping method that has been widely used in various scientific disciplines. The advantages of mind mapping are helping to learn, organizing and storing as much information as possible, and classifying this information fairly so that it allows for quick access. Mind mapping can also serve as a reminder for new thought patterns and behaviors that serve as an important anchor in learning for students (Buzan, 2008; Enright \& White, 2012). Mind mapping is a technique developed by Tony Buzan in which information is presented in a diagrammatic manner using keywords and images that are blasted from a central idea in a format that assists cognitive processing. Mind mapping focuses on meaning rather than grammar and may be more accessible to readers ( $\mathrm{H}$ et al., 2020). Mind mapping is also defined as a learning strategy used for problem solving, organizing ideas, improving memory, storytelling, and exchanging ideas (Kernan et al., 2017).

The method is designed to use words, colors, lines, symbols and images by combining and developing the work potential of the brain that makes it easier for a person to organize and remember all forms of information. By using mind mapping method, students will use high-level note-taking techniques by utilizing the entire brain and making it possible to explore all brain capabilities, namely the left brain and the right brain for thinking and learning purposes. As a very powerful organizational thinking tool, mind mapping makes it easy to place information into the brain and take information outside the brain (Zahro et al., 2018). Mind mapping connects the left brain which contains words, logic, numbers, etc. with the right brain which contains curves, images, colors, etc. so as to make brain performance more synergistic (Dutt, 2015). Mind mapping will make students learn, order, store as much information as possible, classify it naturally, and provide easy and direct access (Arini \& Tristiantari, 2017).

The ability to think critically is important in civic education learning because if students are equipped with critical thinking skills, they will have the skills of the 21st century. Critical thinking is a basic goal in educational practice. It is an important life skill, and there is a broad agreement on the need for critical thinking to improve achievement and deepen understanding across disciplines (Zandvakili et al., 2019). Critical thinking is a combination of abilities, knowledge, attitudes, skills, and processes that individuals who think critically have the ability to ask questions correctly, reduce relevant information, think logically about the information they have obtained, and make reliable conclusions and decisions (Antara et al., 2020; M., Arip \& Nur, 2020). Critical thinking is also defined as a cognitive engine that encourages problem solving and as a logical reflective thinking that focuses on deciding what to believe or do (Dahl et al., 2018; Garrett, 2013). Another definition of critical thinking refers to the skills such as the ability to reason effectively, use systems thinking, evaluate arguments, make judgments, or form appropriate questions (Roohr \& Burkander, 2020). Students who are equipped with critical thinking skills can think meaningfully to guide themselves in making a decision. Furthermore, those who are able to think critically will be 
at a complex level of thinking that they can analyze and evaluate each study to take an action. A person's ability to succeed in life is determined by his/her thinking ability including critical thinking skills, especially in solving his/her life's problems (Dwijananti \& Yulianti, 2010).

In the experimental class group of this research, students who used mind mapping in their learning tended to be more interested and more receptive. They were also better at memorizing the learning materials because they were asked to discuss the materials by making a mind map related to the Insight of Archipelago in the context of the Unitary State of the Republic of Indonesia. They could express themselves using words, colors, lines, symbols, and images by combining and developing the working potential of the brain which makes it easier for a person to organize and remember all forms of information. Mind mapping includes free form and its structure is not limited (M. Davies, 2010). After making a mind map, each group presented the results of the discussion in front of the class. Therefore, students were actively involved in learning. The context of managing classes, skills, presentations, group collaboration, and problem solving are important driving factors for successful mind mapping. Scientifically, mind mapping can help in creativity, memory, presentation skills, group collaboration, and problem solving. In terms of problem solving, improved thinking skills includes critical thinking, whole-brain thinking, and comprehensive thinking (Dutt, 2015). Problem solving skills which include critical thinking is an important step to make students have a clear reference for thinking (Ikhwanuddin et al., 2010). Critical thinking enable people to eliminate the tendency toward bias, prejudice, and uninformed conclusions (Morrissey \& Heilbrun, 2017). Students in control class group whose learning process consisted of lecture and discussion seemed to be passive. Most of them only listened to the lecture and thus their critical thinking skills were not optimum.

Based on the discussion above, it can be concluded that the application of the mind mapping method in civic education learning can increase the level of critical thinking skills of class $X$ students at SMK Negeri 1 Yogyakarta. It can be seen from the way the students took part in learning. The students were directed to analyze, define problems, and collect references to formulate conclusions. This is able to promote students to think first before solving problems, not accepting explanations and then thinking (Ristiasari et al., 2012). Therefore, the implementation of the mind mapping method can be used as a solution to improve students' critical thinking in the learning process to get maximum results and as a provision for the skills needed in the 21 st century, one of which is critical thinking.

\section{Conclusions and Suggestions}

Based on the results of the research and discussion that has been explained, it can be concluded that there was an effect of the application of mind mapping method in learning civics education on the critical thinking skills of class $X$ students of SMK Negeri 1 Yogyakarta. This is indicated by the post-test score of the experimental class group that was greater than the post-test score of the control class group, which means that the application of the mind mapping method is better used in learning. Mind mapping as a learning method can be used as a solution to improve students' critical thinking in the learning process in order to achieve learning goals.

\section{References}

Afandi, Sajidan, Akhyar, M., \& Suryani, N. (2019). Development frameworks of the Indonesian partnership 21 st -century skills standards for prospective science teachers: A Delphi study. Jurnal Pendidikan IPA Indonesia, 8(1), 89-100. https://doi.org/10.15294/jpii.v8i1.11647.

Aliftika, O., Purwanto, \& Utari, S. (2019). Profil keterampilan abad 21 siswa sma pada pembelajaran project based learning (PJBL) materi gerak lurus. WAPFI (Wahana Pendidikan Fisika), 4(2), 141-147.

Antara, I. G. W. S., Sudarma, I. K., \& Dibia, I. K. (2020). The Assessment Instrument of 
Mathematics Learning Outcomes Based on HOTS Toward Two-Dimensional Geometry Topic. Indonesian Journal Of Educational Research and Review, 3(2), 1924. https://doi.org/ijerr.v3i2.25869.g15588.

Arini, N. W., \& Tristiantari, N. K. D. (2017). Essay writing through quantum learning with mind mapping strategy. Jurnal Pendidikan Indonesia, 6(2), 147-153. https://doi.org/10.23887/jpi-undiksha.v6i2.9532.

Boholano, H. (2017). Smart social networking: 21st century teaching and learning skills. Research in Pedagogy, 7(1), 21-29. https://www.ceeol.com/search/articledetail?id=546738.

Buzan, T. (2008). Buku Pintar Mind Map. Gramedia Pustaka Utama.

Changwong, K., Sukkamart, A., \& Sisan, B. (2018). Critical thinking skill development: Analysis of a new learning management model for Thai high schools. Journal of International Studies, 11(2), 37-48. https://doi.org/10.14254/2071-8330.2018/11-2/3.

Cholisin. (2005). Dasar-Dasar IImu Politik. FIS UNY.

Cole, D. R., Ullman, J., Gannon, S., \& Rooney, P. (2015). Critical thinking skills in the international baccalaureate's "theory of knowledge" subject: Findings from an Australian study. Australian Journal of Education, 59(3), 247-264. https://doi.org/10.1177/0004944115603529.

Creswell, J. W. (2016). Research design: Pendekatan metode kualitatif, kuantitatif, dan campuran. Penerjemah Achmad Fawaid dan Rianayati Kusmini P. Pustaka Pelajar.

Dahl, A. J., Peltier, J. W., \& Schibrowsky, J. A. (2018). Critical thinking and reflective learning in the marketing education literature: A historical perspective and future research needs. Journal of Marketing Education, 40(2), 101-116. https://doi.org/10.1177/0273475317752452.

Davies, I., Grammes, T., \& Kun, H. (2017). Citizenship education and character education. Journal of Social Science Education, 16(3), 1-7. https://doi.org/10.4119/UNIBI/jssev16-i3-1716.

Davies, M. (2010). Concept mapping, mind mapping and argument mapping: What are the differences and do they matter. Higher Education, 62(3), 279-301. https://doi.org/10.1007/s10734-010-9387-6.

Dewantara, J. A., I Suhendar, F., R., R., \& Atmaja, T. S. (2019). Pancasila as ideology and characteristics civic education in Indonesia. International Journal for Educational and Vacational Studies, 1(5), 400-405. https://doi.org/10.29103/ijevs.v1i5.1617.

Dutt, M. (2015). Adding value to projects using mind maps. Journal of Creating Value, 1(2), 221-234. https://doi.org/10.1177/2394964315602412.

Dwijananti, P., \& Yulianti, D. (2010). Pengembangan kemampuan berpikir kritis siswa melalui pembelajaran problem base instruction pada mata kuliah fisika lingkungan. Jurnal Pendidikan Fisika Indonesia, 6(2), 108-114. https://doi.org/10.15294/jpfi.v6i2.1122.

Elicor, P. P. E. (2016). Critical thinking and community of inquiry within professional organizations in the developing world. Journal of Human Values, 23(1), 13-20. https://doi.org/10.1177/0971685816673479.

Enright, S. M., \& White, S. J. (2012). Using mind mapping to anchor learning: Focus on leader's decision domains. Hospital Pharmacy, 47(7), 560-563. https://doi.org/10.1310/hpj4707-560.

Garrett, M. L. (2013). An examination of critical thinking skills in high school choral rehearsals. Journal of Research in Music Education, 61(3), 03-317. https://doi.org/10.1177/0022429413497219.

H, Y., Gao, X.-B., Li, M.-H., Ye, Q., Sun, Y., \& Huang, Y. (2020). The use of mind mapping in health education in extended care for children with caries. Journal of International Medical Research, 48(5), 1-8. https://doi.org/10.1177/0300060519898053.

Habiby, Nita, A., \& Nuraini, M. (2017). Manajemen adaptasi pembelajaran kurikulum 2013 ke kurikulum 2006 (KTSP) SDN Sondakan Surakarta. Profesi Pendidikan Dasar, 4(2), 180-189.

Hamdu, G., Fuadi, F. N., Yulianto, A., \& Akhirani, Y. S. (2020). Items quality analysis using rasch model to measure elementary school students' critical thinking skill on stem 
learning. Jurnal Pendidikan Indonesia (JPI), 9(1), 61-74. https://doi.org/10.23887/jpiundiksha.v9i1.20884.

Handayani, N. (2017). Becoming the effective english teachers in the 21st century: What should know and what should do? 1st. English Language and Literature International Conference (ELLIC), 156-164.

Hewett, K. J. E., Pletcher, B. C., \& Zeng, G. (2018). The 21st-century classroom gamer. Games and Culture. 15(2), 198-223. https://doi.org/10.1177/1555412018762168.

Hung, C.-Y. (2014). The use of weblogs in citizenship education: A theoretical analysis of the integration of weblogs and the english citizenship curriculum. E-Learning and Digital Media, 11(4), 350-362. https://doi.org/10.2304\%2Felea.2014.11.4.350.

Ikhwanuddin, Jaedun, A., \& Puwantoro, D. (2010). Problem solving dalam pembelajaran fisika untuk meningkatkan kemampuan mahasiswa berpikir analitis. Jurnal Kependidikan, 40(2), 215-230. https://doi.org/10.21831/jk.v40i2.500.

In'am, A., \& Hajar, S. (2017). Learning geometry through discovery learning using a scientific approach. International Journal of Instruction, 10(1). https://doi.org/10.12973/iji.2017.1014a.

Jan, H. (2017). Teacher of 21st century: Characteristics and development. Research on Humanities and Social Sciences, 7(9), 50-54.

Kernan, W. D., Basch, C. H., \& Cadorett, V. (2017). Using mind mapping to identify research topics: A lesson for teaching research method. Pedagogy in Health Promotion, 4(2), 101-107. https://doi.org/10.1177/2373379917719729.

Kettler, T. (2014). Critical thinking skills among elementary school students: Comparing identified gifted and general education student performance. Gifted Child Quarterly, 58(2), 127-136. https://doi.org/10.1177/0016986214522508.

Khoeriyah, N., \& Mawardi, M. (2018). Penerapan Desain Pembelajaran Tematik Integratif Alternatif Berbasis Kearifan Lokal untuk Meningkatkan Hasil dan Kebermaknaan Belajar. Mimbar Sekolah Dasar, 5(2), 63. https://doi.org/10.17509/mimbarsd.v5i2.11444.

Kong, S. C. (2015). An experience of a three-year study on the development of critical thinking skills in flipped secondary classrooms with pedagogical and technological support. Computers \& Education, 89, 16-31. https://doi.org/10.1016/j.compedu.2015.08.017.

Lee, S. Y. (2015). Civic education as a means of talent dissemination for gifted students. Asia Pacific Education Review, 16(2), 307-316. https://doi.org/10.1007/s12564-0159372-y.

Lilawati, A. (2020). Peran Orang Tua dalam Mendukung Kegiatan Pembelajaran di Rumah pada Masa Pandemi. Jurnal Obsesi : Jurnal Pendidikan Anak Usia Dini, 5(1), 549. https://doi.org/10.31004/obsesi.v5i1.630.

M., Arip, A. G. R., \& Nur, S. H. (2020). Implementation of problem-based learning model assisted by e-modules on students' critical thinking ability. Jurnal Pendidikan Indonesia, 9(3), 339-346. https://doi.org/10.23887/jpi-undiksha.v9i3.22410.

Machdel, M., \& Marita, T. (2019). Teaching critical thinking, problem solving and design thinking: Preparing IS students for the future. Journal of Information Systems Education, 30(4), 242-252.

Mahanal, S., Zubaidah, S., Sumiati, I. D., Sari, T. M., \& Ismirawati, N. (2019). RICOSRE: A learning model to develop critical thinking skills for students with different academic abilities. International Journal of Instruction, 12(2), 417-434. https://doi.org/10.29333/iji.2019.12227a.

Mehta, S. R., \& Al-Mahrooqi, R. (2014). Can thinking be taught? Linking critical thinking and writing in an EFL context. RELC Journal, 46(1), 23-36. https://doi.org/10.1177/0033688214555356.

Morrissey, B., \& Heilbrun, M. E. (2017). Teaching critical thinking in graduate medical education: Lessons learned in diagnostic radiology. Journal of Medical Education and Curricular Development, 4, 1-5. https://doi.org/10.1177/2382120517696498.

Print, M., \& Lange, D. (2013). Civic education and competences for engaging citizens in 
democracies. Sense Publishers.

Rachmadtullah, R., \& Wardani, P. A. (2016). Peningkatan hasil belajar pendidikan kewarganegaraan melalui metode pembelajaran contexstual and learning. Jurnal Pendidikan Dasar, 7(1), 116-127. https://doi.org/10.21009/JPD.071.10.

Ristiasari, T., Priyono, B., \& Sukaesih, S. (2012). Model pembelajaran problem solving dengan mind mapping terhadap kemampuan berpikir kritis siswa. Unnes Journal of Biologi Education, 1(3), 34-41. https://doi.org/10.15294/jbe.v1i3.1498.

Rohmawati, E., Widodo, W., \& Agustini, R. (2018). Membangun kemampuan literasi sains siswa melalui pembelajaran berkonteks socio-scientific issues berbantuan media weblog. Jurnal Penelitian Pendidikan IPA, 3(1). https://doi.org/10.26740/jppipa.v3n1.p8-14.

Roohr, K. C., \& Burkander, K. (2020). Exploring critical thinking as an outcome for students enrolled in community colleges. Community College Review, 48(3), 330-351. https://doi.org/10.1177/0091552120923402.

Samsuri. (2013). Pendidikan kewarganegaraan. Ar-ruzz Media.

Santosa, M. H. (2017). Learning approaches of Indonesian EFL Gen Z students in a Flipped Learning context. Journal on English as a Foreign Language, 7(2), 183. https://doi.org/10.23971/jefl.v7i2.689.

Schulz, W., Ainley, J., Fraillon, J., Losito, B., Agrusti, G., \& Friedman, T. (2016). Becoming citizens in a changing world. Springer.

Shaw, A., Liu, O. L., Gu, L., \& Kardonova, E. (2019). Thinking critically about critical thinking: Validating the russian heighten critical thinking assessment. Studies in Higher Education, 45(9), 1-16. https://doi.org/10.1080/03075079.2019.1672640.

Shume, R., Lam, C., \& Laabs, B. (2012). Ensuring good character and civic education: Connecting through service learning. Asia Pasific Journal of Education, 32(4), 430440. https://doi.org/10.1080/02188791.2012.741768.

Sudarmiani, S. (2013). Membangun Karakter Anak Dengan Budaya Kearifan Lokal Dalam Proses Pembelajaran Di Sekolah. EQUILIBRIUM: Jurnal IImiah Ekonomi Dan Pembelajarannya, 1(1), 54-72. https://doi.org/10.25273/equilibrium.v1i1.556.

Sugiyono. (2014). Metode Penelitian Pendidikan Pendekatan Kuantitatif, Kualitatif, dan R\&D. Alfabeta.

Sujana, I. W. C. (2019). Fungsi Dan Tujuan Pendidikan Indonesia. Adi Widya: Jurnal Pendidikan Dasar, 4(1), 29. https://doi.org/10.25078/aw.v4i1.927.

Swalwell, K., \& Payne, K. A. (2019). Critical civic education for young children. Multicultural Perspectives, 21(2), 127-132. https://doi.org/10.1080/15210960.2019.1606641.

Taufik, M. S., Mustami, M. K., \& Damayanti, E. (2018). Pengaruh model pembelajaran synectics, mind maps, cooperative learning (SM2CL) terhadap kemampuan berpikir kritis siswa. Jurnal Biotek, 6(2), 61-72. https://doi.org/10.24252/jb.v6i2.5378.

Vasil, M. (2020). Using popular music pedagogies to foster 21st-century skills and knowledge. Ational Association for Music Education, 33(3), 46-51. https://doi.org/10.1177\%2F1048371320902752.

Zahro, F., Degeng, I. N. S., \& Mudiono, A. (2018). Pengaruh model pembelajaran student team achievement devision (STAD) dan mind mapping terhadap hasil belajar siswa kelas IV sekolah dasar. Premiere Educandum: Jurnal Pendidikan Dasar Dan Pembelajaran, 8(2), 196-205.

Zandvakili, E., Washington, E., \& Gordon, E. (2019). Teaching patterns of critical thinking: The 3CA model-concept maps, critical thinking, collaboration, and assessment. SAGE Open, 9(4), 1-15. https://doi.org/10.1177/2158244019885142. 